\title{
Association between serum osteocalcin, adiposity and metabolic risk in obese children and adolescents
}

\author{
Związek pomiędzy surowiczym stężeniem osteokalcyny, otłuszczeniem ciała \\ i zaburzeniami metabolicznymi u dzieci i młodzieży z otyłością
}

\section{Barbara Garanty-Bogacka', Małgorzata Syrenicz'1, Monika Rać², Beata Krupa ${ }^{1}$, Grażyna Czaja-Bulsa ${ }^{3}$, Mieczysław Walczak ${ }^{4}$, Elżbieta Sowińska-Przepiera ${ }^{5}$, Anhelli Syrenicz ${ }^{5}$}

\author{
${ }^{1}$ Independent Laboratory of Propaedeutics of Children's Diseases, Pomeranian Medical University, Szczecin, Poland \\ ${ }^{2}$ Department of Biochemistry and Medical Chemistry, Pomeranian Medical University, Szczecin, Poland \\ ${ }^{3}$ Paediatric Nursery Unit, Pomeranian Medical University, Szczecin, Poland \\ ${ }^{4}$ Department of Paediatrics, Endocrinology, Diabetology, Inborn Errors of Metabolism and Cardiology, Pomeranian Medical \\ University, Szczecin, Poland \\ ${ }^{5}$ Department of Endocrinology, Metabolic Diseases and Internal Diseases, Pomeranian Medical University, Szczecin, Poland
}

\begin{abstract}
Introduction: Childhood obesity has been associated with the development of insulin resistance, potentially leading to several metabolic disorders. Osteocalcin has been reported to contribute to the regulation of glucose tolerance and insulin sensitivity.

The purpose of this study was to examine the relationship between serum osteocalcin and metabolic risk factors in obese children and adolescents.

Material and methods: Age, gender, pubertal stage, adiposity markers (standard deviation score of body mass index: BMI-SDS, percentage of body fat, waist circumference), blood pressure, serum osteocalcin (OC), fasting plasma glucose and insulin, glycated haemoglobin level $\left(\mathrm{HbA}_{1 \mathrm{c}}\right)$, insulin resistance estimated by homeostasis model assessment (HOMA-IR), lipid profile, C-reactive protein (CRP), fibrinogen (FB), white blood cell count (WBC) and 25-hydroxyvitamin D (25-OH-D) were evaluated in 142 obese children and adolescents. Stepwise multiple regression analysis was used to determine the relationship between serum osteocalcin and metabolic risk parameters.

Results: Mean serum osteocalcin level was $72.0 \pm 20.5 \mu \mathrm{g} / \mathrm{L}$ (range: 16.8-181.5 $\mu \mathrm{g} / \mathrm{L}$ ). After adjustment for multiple potential confounders, serum osteocalcin concentration was inversely associated with adiposity markers as well as HOMA-IR, $\mathrm{HbA}$, triglycerides, CRP, FB and positively with 25-OH-D and HDL-cholesterol. In stepwise multiple linear regression analysis adjusted for age, gender and pubertal stage, osteocalcin was significantly negatively related to HOMA-IR, triglycerides and waist circumference.

Conclusions: Serum osteocalcin concentration is associated with blood markers of dysmetabolic phenotype and measures of adiposity, suggesting that osteocalcin is important not only for bones but also for glucose and fat metabolism as early as during childhood.

(Endokrynol Pol 2013; 64 (5): 346-352)
\end{abstract}

Key words: adolescents, children, metabolic disorders, obesity, osteocalcin

\section{Streszczenie}

Wstęp: Otyłość u dzieci wiąże się z rozwojem insulinooporności i ryzykiem wielu zaburzeń metabolicznych. Osteokalcyna odgrywa rolę w kształtowaniu tolerancji glukozy oraz wrażliwości na insulinę. Celem pracy było zbadanie zależności pomiędzy stężeniem osteokalcyny w surowicy a czynnikami ryzyka zaburzeń metabolicznych u dzieci i młodzieży.

Materiał i metody: Wśród czynników ryzyka zaburzeń metabolicznych, których związek ze stężeniem osteokalcyny w surowicy analizowano w modelu wielokrotnej regresji krokowej w grupie 142 otyłych dzieci i młodzieży, znalazły się: płeć, stopień dojrzałości płciowej, markery otłuszczenia (odchylenie standardowe wskaźnika masy ciała: BMI-SDS, odsetek tkanki tłuszczowej, obwód talii), ciśnienie tętnicze krwi, stężęnie osteokalcyny w surowicy, stężenie glukozy i insuliny na czczo, zawartość hemoglobiny glikowanej $\left(\mathrm{HbA}_{11}\right)$, stopień oporności na insulinę oceniany na podstawie modelu homeostatycznego (HOMA-IR), profil lipidowy, stężenie białka C-reaktywnego (CRP) i fibrynogenu (FB), liczba krwinek białych oraz stężenie 25-hydroksywitaminy D (25-OH-D).

Wyniki: Średnie stężenie osteokalcyny w surowicy wyniósł 72,0 \pm 20,5 $\mu \mathrm{g} / \mathrm{l}$ (zakres: 16,8-181,5 $\mu \mathrm{g} / \mathrm{L}$ ). Po uwzględnieniu poprawki na potencjalne czynniki zakłócające, stężenie osteokalcyny okazało się być odwrotnie skorelowane z poziomem markerów otłuszczenia, a także z HOMA-IR, $\mathrm{HbA}_{1 c^{c}}$ stężeniem triglicerydów, CRP i FB; stwierdzono też dodatnią korelację ze stężeniem 25-OH-D i HDL. W modelu wielokrotnej regresji krokowej, uwzględniającym poprawkę na wiek, płeć oraz stopień dojrzałości płciowej, stężenie osteokalcyny okazało się być odwrotnie skorelowane z HOMA-IR, stężeniem triglicerydów i obwodem talii.

Wnioski: Stężenie osteokalcyny w surowicy wykazuje związek z wykładnikami zaburzeń metabolicznych oraz miernikami otłuszczenia; obok udziału w metabolizmie tkanki kostnej, osteokalcyna wydaje się więc odgrywać istotną rolę w przemianach glukozy i lipidów u dzieci. (Endokrynol Pol 2013; 64 (5): 346-352)

Słowa kluczowe: osteokalcyna, zaburzenia metaboliczne, otyłość, dzieci, młodzież 


\section{Introduction}

Childhood obesity is known to be an important risk factor for the development of insulin resistance potentially leading to several metabolic conditions such as impaired glucose tolerance, type 2 diabetes, atherosclerosis and hypertension [1]. Abnormalities of bone metabolism are quite often found in patients with obesity and glucose disturbances, especially in diabetic subjects. Even overweight children are prone to fractures, although their bone mineral density may not be particularly low [2]. Over the past decade, it has been shown that bone-associated proteins, such as osteocalcin, osteopontin, and osteoprotegerin are found in atherosclerotic arteries, suggesting that these molecules could be associated with vascular diseases [3]. More recently, experimental studies have confirmed that the skeleton is not only an organ of locomotion but may act as an endocrine organ which participates in energy metabolism and glucose homeostasis through secretion of an osteoblast-derived protein-osteocalcin [4,5]. Osteocalcin, a known marker of bone formation, decreases visceral fat mass, increases energy expenditure, and promotes insulin sensitivity by increasing the number of pancreatic $\beta$-cells and insulin secretion. Lee et al. [4] showed that mice lacking osteocalcin have an increased amount of visceral fat and display glucose intolerance, insulin resistance and increased serum triglyceride levels compared to wildtype mice. Moreover, injections of osteocalcin improve glucose metabolism and prevent the development of type 2 diabetes in mice [6]. Although these findings confirm the hypothesis of a regulatory hormonal loop between bone and adipose tissue, little is known about whether serum osteocalcin concentration is associated with fat mass, glucose, insulin, and atherosclerosis risk factors in children. In this study, we investigate the relationship between serum osteocalcin level and the parameters of adiposity as well as blood markers characteristic of the dysmetabolic phenotype in obese children and adolescents.

\section{Material and methods}

\section{Study group}

The participants in this study were 142 obese subjects (68 boys and 74 girls), aged $6-18$ years, attending the Outpatients Clinic for Children with Metabolic Disorders. Obesity was recognised on the basis of a Body Mass Index $(\mathrm{BMI})>97^{\text {th }}$ percentile for age and sex on the BMI percentile charts for the Polish population of children and adolescents [7]. Children with acute or chronic infections, as well as children with significant medical conditions such as genetic syndromes, cancers, autoimmunologic diseases, hepatic or renal dysfunction, hormonal abnormalities or diabetes, were excluded. No patients were taking medications such as corticosteroids, vitamin D or calcium, nor were any drinking alcohol or smoking cigarettes.

The protocol of this study was approved by the Ethical Committee of the Pomeranian Medical University. Written parental consent and patients' assent were obtained before entering the study.

\section{Anthropometric and clinical measurements}

All anthropometric measurements (height, weight and waist circumference) were carried out by the same trained staff, with the patients wearing only underwear. Height was measured using a wall-mounted Harpender's stadiometer, and weight was measured on an electronic scale. Body mass index (BMI) was calculated by dividing weight (in $\mathrm{kg}$ ) by height in square metres $\left(\mathrm{kg} / \mathrm{m}^{2}\right)$. Since BMI changes with age during childhood, the BMI-standard deviation score (BMISDS) was also calculated [7]. The waist circumference was measured as a minimal abdominal circumference, between the xiphoid process and iliac crest. Because the waist circumference increases with age, it was expressed as a standard deviation score (waist-SDS) [8]. Percentage body fat (\% FAT) and fat mass (in kg) were measured in the fasted state using the bioimpedance methods and a fixed-frequency $(50 \mathrm{kHz})$ bioimpedance analysis analyser (Bioelectrical Impedance Analyzer Tanita 131, Japan) with an applied current of $0.8 \mathrm{~mA}$.

Physical examination was performed to check the general health status as well as determine the pubertal status, according to the criteria of Tanner. In girls, breast stage was used if there was a discrepancy between breast and pubic hair development, whereas in boys, pubic hair was used if there was a discrepancy between genitalia and pubic hair staging.

Ambulatory blood pressure monitoring (ABPM) was performed using a Mobil-O-Graph device, which uses the oscillometric method. Systolic (SBP) and diastolic blood pressure (DBP) were measured halfhourly between 7 a.m. and 11 p.m., and hourly between 11 p.m. and 7 a.m.

For the purposes of serum vitamin D analysis, we defined seasons by months: winter (December-May) and summer (June-November).

\section{Blood analyses}

All measurements were made in the morning after a 12-h overnight fast. Serum osteocalcin was measured by immunoradiometric assay (OSTEO-RIACT, IBA CIS $\mathrm{BIO}, \mathrm{F}$ ) with intra-a and inter-assay CVs of 4.0 and $6.0 \%$, respectively. The assay detects both uncarboxylated and carboxylated osteocalcin. Serum 25-OH-D level was measured using Nichols radioimmunoassay (Nichols Institute, San Clemente, CA, USA). Glucose was measured with the glucose oxidase technique (Glucose HK Analyzer, Olym- 
Table I. Clinical features and metabolic parameters in study participants

Tabela I. Charakterystyki kliniczne i metaboliczne uczestników badania

\begin{tabular}{|c|c|c|c|}
\hline \multicolumn{2}{|c|}{ Demographic and clinical } & \multicolumn{2}{|c|}{ Glucose/insulin metabolism } \\
\hline Age (years) & $13.8 \pm 2.6$ & Glucose $[\mathrm{mmol} / \mathrm{L}]$ & $5.1 \pm 0.4$ \\
\hline Sex [male/female] & $68 / 74$ & Insulin [mU/L] & $20.4 \pm 10.7$ \\
\hline Tanner stage [1-5] & $19,23,25,11,63$ & HOMA-IR & $4.8 \pm 2.5$ \\
\hline Weight [kg] & $80.1 \pm 20.3$ & $\mathrm{HbA} 1 \mathrm{c}(\%)$ & $5.5 \pm 0.3$ \\
\hline $\mathrm{BMI}[\mathrm{kg} / \mathrm{m} 2]$ & $30.1 \pm 4.4$ & Lipid profile & \\
\hline BMI-SDS & $3.8 \pm 1.4$ & T-chol [mg/dL] & $170.3 \pm 26.8$ \\
\hline$\%$ body fat & $35.0 \pm 4.9$ & HDL-chol [mg/dL] & $46.9 \pm 10.4$ \\
\hline Fat mass $[\mathrm{kg}]$ & $28.2 \pm 9.5$ & LDL-chol [mg/dL] & $102.9 \pm 26.0$ \\
\hline Waist [cm] & $101.8 \pm 13.6$ & $\mathrm{TG}[\mathrm{mg} / \mathrm{dL}]$ & $121.9 \pm 37.9$ \\
\hline Waist-SDS & $4.3 \pm 1.6$ & Inflammatory markers & \\
\hline $\mathrm{SBP}[\mathrm{mm} \mathrm{Hg}]$ & $124.4 \pm 11.2$ & $\mathrm{CRP}[\mathrm{mg} / \mathrm{L}]$ & $1.3 \pm 0.5$ \\
\hline \multirow[t]{5}{*}{$\mathrm{DBP}[\mathrm{mm} \mathrm{Hg}]$} & $80.4 \pm 10.1$ & $\mathrm{FB}[\mathrm{mg} / \mathrm{dL}]$ & $315.9 \pm 58.5$ \\
\hline & & WBC [G/L] & $7.0 \pm 1.6$ \\
\hline & & Bone markers & \\
\hline & & Osteocalcin [ng/mL] & $72.0 \pm 40.5$ \\
\hline & & 25-OH-D [ng/mL] & $12.4 \pm 6.8$ \\
\hline
\end{tabular}

Data is presented as mean $\pm S D$

pus, Japan). Free insulin concentration was determined by a commercial radioimmunoanalysis - RIA (Pharmacia RIA kit). Glycated haemoglobin $\left(\mathrm{HbA}_{1 \mathrm{c}}\right)$ level was measured by the immunoturbimetric method (Olympus, Japan). Determination of serum concentration of $\mathrm{C}$-reactive protein (CRP) was performed using the high-sensitivity assay based on the immunoturbidimetric method (Olympus). Total cholesterol (T-chol), HDL cholesterol (HDL-chol) and triacylglycerol (triglycerides-TG) were measured by automated enzymatic procedures (Olympus). LDL cholesterol (LDL-chol) was determined after separating LDL fraction of cholesterol from fresh serum by sequential ultracentrifugation, using an Olympus commercial kit. White blood cell count was measured by a commercial kit (Olympus).

Insulin resistance was estimated using the homeostatic model assessment index (HOMA-IR) calculated according to the following formula: HOMA-IR = fasting blood glucose $(\mathrm{mmol} / \mathrm{L}) \times$ fasting insulin $(\mathrm{mU} / \mathrm{L}) / 22.5$ [9].

\section{Statistical analysis}

Statistical analysis was performed using the STATA 11 software package. Conformity to a normal distribution was tested by the Kołmogorov-Smirnov test. For quantitative variables that were normally distributed, results are expressed as mean value \pm standard deviation (SD).

Statistically significant differences were tested for quantitative items by the Student's t-test, and for qualitative items by the $\chi^{2}$ test. The cohort of patients was also divided into quartiles by osteocalcin concentration.
Since the number of patients in the $2^{\text {nd }}$ and $3^{\text {rd }}$ quartiles was relatively small (19 and 20 subjects, respectively), they were analysed and presented collectively. For comparisons among the three groups, one-way analysis of variance for independent samples was used. Association between serum OC levels and adiposity markers (BMI-SDS, percentage of body fat, waist-SDS) as well as biochemical parameters were examined with Pearson's correlation. A stepwise multiple linear regression analysis for serum osteocalcin (as an independent variable) and other clinical and analytical markers of metabolic risk was performed. Statistical significance for all analyses was set at $\mathrm{p}<0.05$.

\section{Results}

The general characteristics of children participating in this study are presented in Table I.

Serum osteocalcin level was significantly higher in boys than in girls $(79.1 \pm 27.6$ v. $65.5 \pm 32.2 \mathrm{ng} / \mathrm{mL}$; $\mathrm{p}=0.044$; data not shown). Pubertal stage and season were not associated with serum $\mathrm{OC}(\mathrm{P}=0.074$ and $\mathrm{p}=0.725$, respectively).

When we divided the cohort into quartiles by serum osteocalcin concentration (with the $2^{\text {nd }}$ and $3^{\text {rd }}$ quartile analysed together), anthropometric and biochemical parameters varied inversely with $\mathrm{OC}$ quartile with the exception of age and serum 25-OH-D level (Table II).

In the correlation analysis, performed in the whole group, circulating osteocalcin was inversely associated 
Table II. Characteristics of studied patients divided by osteocalcin quartile

Tabela II. Charakterystyki badanych pacjentów w zależności od tercyla stężenia osteokalcyny

\begin{tabular}{|c|c|c|c|c|}
\hline & \multicolumn{4}{|c|}{ Osteocalcin quartile $[\mathrm{ng} / \mathrm{mL}]$} \\
\hline & $\leq 34.6$ & $34.7-97.0$ & $\geq 97.1$ & $\mathrm{p}$ value \\
\hline & $\begin{array}{l}\text { 1st quartile } \\
(\mathrm{n}=44)\end{array}$ & $\begin{array}{c}\text { 2nd and 3rd quartile } \\
(n=39 \text {, i.e. } 19+20)\end{array}$ & $\begin{array}{l}\text { 4th quartile } \\
\text { (n = 59) }\end{array}$ & \\
\hline \multicolumn{5}{|c|}{ Demographic and clinical } \\
\hline Age (years) & $15.5 \pm 1.9$ & $13.0 \pm 2.7$ & $13.6 \pm 2.4$ & $<0.001$ \\
\hline Weight [kg] & $85.8 \pm 20.7$ & $75.7 \pm 21.6$ & $72.9 \pm 15.1$ & 0.002 \\
\hline $\mathrm{BMI}\left[\mathrm{kg} / \mathrm{m}^{2}\right]$ & $34.3 \pm 5.4$ & $29.5 \pm 4.4$ & $28.9 \pm 1.2$ & 0.027 \\
\hline BMI-SDS & $4.8 \pm 1.4$ & $3.8 \pm 1.4$ & $3.2 \pm 1.2$ & 0.050 \\
\hline$\%$ body fat & $45.7 \pm 5.9$ & $36.9 \pm 4.6$ & $32.4 \pm 4.8$ & 0.001 \\
\hline Fat mass [kg] & $30.5 \pm 10.7$ & $29.1 \pm 8.4$ & $26.5 \pm 9.4$ & 0.019 \\
\hline Waist [cm] & $107.4 \pm 14.2$ & $99.8 \pm 13.2$ & $95.4 \pm 12.5$ & 0.002 \\
\hline Waist-SDS & $5.0 \pm 1.7$ & $4.2 \pm 1.3$ & $3.7 \pm 1.7$ & $<0.001$ \\
\hline $\mathrm{SBP}[\mathrm{mm} \mathrm{Hg}]$ & $130.4 \pm 9.8$ & $122.2 \pm 10.9$ & $115.6 \pm 11.3$ & $<0.001$ \\
\hline $\mathrm{DBP}[\mathrm{mm} \mathrm{Hg}]$ & $85.3 \pm 10.9$ & $79.3 \pm 8.8$ & $76.6 \pm 10.2$ & $<0.001$ \\
\hline \multicolumn{5}{|c|}{ Glucose/insulin metabolism } \\
\hline Glucose $[\mathrm{mmol} / \mathrm{L}]$ & $5.2 \pm 0.4$ & $5.1 \pm 0.4$ & $5.0 \pm 0.3$ & 0.443 \\
\hline Insulin $[\mathrm{mU} / \mathrm{L}]$ & $26.6 \pm 12.3$ & $19.5 \pm 9.8$ & $15.9 \pm 7.7$ & $<0.001$ \\
\hline HOMA-IR & $6.1 \pm 2.8$ & $4.5 \pm 2.0$ & $3.5 \pm 1.7$ & $<0.001$ \\
\hline $\mathrm{HbA}_{1 \mathrm{c}}(\%)$ & $5.6 \pm 0.3$ & $5.5 \pm 0.3$ & $5.2 \pm 0.3$ & $<0.001$ \\
\hline \multicolumn{5}{|l|}{ Lipid profile } \\
\hline T-chol [mg/dL] & $175.1 \pm 32.6$ & $169.2 \pm 26.1$ & $167.7 \pm 21.3$ & 0.522 \\
\hline HDL-chol [mg/dL] & $41.8 \pm 9.9$ & $47.6 \pm 9.7$ & $50.7 \pm 10.7$ & $<0.001$ \\
\hline LDL-chol [mg/dL] & $111.9 \pm 29.7$ & $102.1 \pm 24.7$ & $95.3 \pm 22.2$ & 0.003 \\
\hline $\mathrm{TG}[\mathrm{mg} / \mathrm{dL}]$ & $153.9 \pm 47.8$ & $117.5 \pm 52.9$ & $98.3 \pm 41.1$ & 0.001 \\
\hline \multicolumn{5}{|c|}{ Inflammatory markers } \\
\hline $\mathrm{CRP}[\mathrm{mg} / \mathrm{L}]$ & $1.7 \pm 0.8$ & $1.3 \pm 0.4$ & $1.0 \pm 0.5$ & $<0.001$ \\
\hline $\mathrm{FB}[\mathrm{mg} / \mathrm{dL}]$ & $358.3 \pm 52.7$ & $308.3 \pm 49.1$ & $288.4 \pm 59.0$ & $<0.001$ \\
\hline WBC $[\mathrm{G} / \mathrm{L}]$ & $7.5 \pm 1.7$ & $7.0 \pm 1.5$ & $6.7 \pm 1.5$ & 0.027 \\
\hline \multicolumn{5}{|l|}{ Bone markers } \\
\hline 25-OH-D [ng/mL] & $9.1 \pm 3.8$ & $12.6 \pm 6.1$ & $16.2 \pm 7.3$ & $<0.001$ \\
\hline
\end{tabular}

Data is presented as mean $\pm \mathrm{SD}$

with markers of the dysmetabolic phenotype, BMI-SDS $(\mathrm{r}=0.23 ; \mathrm{p}<0.01)$, \% FAT $(\mathrm{r}=0.22 ; \mathrm{p}<0.01)$, fat mass $(\mathrm{r}=0.29 ; \mathrm{p}<0.001)$, waist-SDS $(\mathrm{r}=0.36 ; \mathrm{p}<0.001)$, CRP $(r=0.38 ; p<0.001)$, WBC $(r=0.25 ; p<0.01)$, fasting insulin $(\mathrm{r}=0.45 ; \mathrm{p}<0.001), \mathrm{HOMA}-\mathrm{IR}(\mathrm{r}=0.43$; $\mathrm{p}<0.001)$, LDL-chol $(\mathrm{r}=0.27 ; \mathrm{p}<0.01)$, triglicerydes $(\mathrm{r}=0.42 ; \mathrm{p}<0.001), \mathrm{FB}(\mathrm{r}=0.52 ; \mathrm{p}<0.001), \mathrm{HbA}_{1 \mathrm{c}}$ $(\mathrm{r}=0.45 ; \mathrm{p}<0.001)$, SBP $(\mathrm{r}=0.36 ; \mathrm{p}<0.001)$, DBP $(\mathrm{r}=0.34 ; \mathrm{p}<0.001)$ after adjustment for age, sex, pubertal stage and season. Positive correlations between serum osteocalcin and HDL-chol $(\mathrm{r}=0.37$; $\mathrm{p}<0.001)$ and 25-OH-D ( $\mathrm{r}=0.38 ; \mathrm{p}<0.001)$ were also found.

Stepwise multiple regression analysis for OC and the remaining analysed variables showed a negative correlation with insulin resistance index $(\mathrm{r}=0.33$; $\mathrm{p}<0.001)$, triglycerides $(\mathrm{r}=0.22 ; \mathrm{p}<0.01)$ and waist-SDS $(\mathrm{r}=0.18 ; \mathrm{p}<0.05)$. Neither CRP nor 25-OH-D correlated with serum osteocalcin level by this stepwise regression model (Table III).

\section{Discussion}

In this study performed in obese children and adolescents, we found that serum osteocalcin was inversely associated with blood and adiposity markers of the dysmetabolic phenotype, including insulin resistance, abnormal lipid profile, systemic inflammation and body fatness. This was confirmed by differences in 
Table III. Stepwise multiple regression analysis between serum osteocalcin and different metabolic risk parameters in obese children*

Tabela III. Model wielokrotnej regresji krokowej oceniajacy związek pomiędzy stężeniem osteokalcyny w surowicy a różnymi czynnikami ryzyka zaburzeń metabolicznych $u$ dzieci z otyłościq ${ }^{*}$

\begin{tabular}{lccc}
\hline Variable & $\mathbf{r}$ & p value & $\begin{array}{l}\text { R for stepwise } \\
\text { regression model }\end{array}$ \\
\hline HOMA-IR & -0.33 & $<0.001$ & 0.63 \\
\hline TG & -0.22 & 0.003 & \\
\hline Waist-SDS & -0.18 & 0.033 & \\
\hline
\end{tabular}

${ }^{*}$ After adjustment for age, gender and pubertal stage

OC concentrations according to adiposity status and metabolic risk profile. Serum osteocalcin decreases with increasing percent of body fat and waist circumference as well as insulin concentration, $\mathrm{HOMA}-\mathrm{IR}, \mathrm{HbA}_{1 \mathrm{c}}$ and inflammatory markers. Moreover, low serum 25-OHD concentration, a known marker for dysmetabolic phenotype, was also correlated with low circulating OC. These findings suggest that osteocalcin acts as a negative regulator of fat mass and has favourable effects on fat and glucose metabolism in obese children.

A reciprocal interaction between bone and energy metabolism has long been suspected, based on clinical observations that obesity is inversely associated with osteoporosis. It is now known from experimental studies that there is an endocrine regulation of glucose and fat metabolism by the skeleton, via osteoblast-secretory product - osteocalcin $[4,5,10]$. Recent human studies have also shown a relationship between $O C$ and fat and carbohydrate metabolism [11, 12]. Osteocalcin has been reported to be decreased in patients with type 2 diabetes $[13,14]$, negatively correlated with fasting plasma glucose, $\mathrm{HbA}_{1 \mathrm{c}^{\prime}}$ insulin resistance, C-reactive protein and BMI [15, $16]$, and increased with improved glycaemic control [12, 17]. There is increasing evidence that serum osteocalcin level is associated with the presence of metabolic syndrome $[18,19]$. These are consistent with the results of our study in which significant correlations between circulating osteocalcin and several parameters of dysmetabolic phenotype, such as abdominal obesity, insulin resistance, and serum triglycerides, were also found. It is commonly accepted that the presence of metabolic syndrome increases the risk of mortality from cardiovascular diseases (CVD). Therefore, reduced level of osteocalcin might modulate cardiovascular risk. The recent study by Yeap et al. [20] showed that total OC predicts all-cause and CVD-related mortality in older men. However, this relationship was U-shaped which suggests that both men with low and those with high osteocalcin levels have increased risk of CVD-induced mortality.

Data concerning serum osteocalcin in children is limited and results are often controversial [21-24]. Serum osteocalcin levels have been found to be lower in obese than in non-obese children [22] and correlated inversely with both BMI and body fat [23, 25]. However, the correlation between OC and body composition was most significant for absolute fat mass compared to other indices of adiposity (\% of body fat, BMI, or BMI-SDS) [25]. These results suggest that circulating osteocalcin is more influenced by absolute fat mass than by proportion of body fat. In our study, the percentage of body fat and fat mass was determined by the bioimpedance method, using novel Tanita body-fat analyser. Methods of body fat determination are considered either as 'reference' or 'prediction' techniques. Reference methods, such as body density, total body water, or dual-energy X-ray absorptiometry (DXA), determine certain physical properties of the body, whereas prediction methods, e.g. skinfold thicknesses and bioelectrical impedance, use regression analysis to estimate the outcome of one or more reference techniques; traditionally, these are total body water measurements for bioelectrical impedance and body density for skinfold thicknesses. Jebb et al. [26] demonstrated that the practical simplicity of the bioimpedance method in Tanita analyser was not associated with a clinically significant decrease in performance compared to the reference methods. Regarding body composition, a study of prepubertal overweight children with prediabetes showed that greater levels of central fat rather than total adiposity may be deleterious for the developing bone [24]. This is in concordance with the results of our study, in which serum OC correlated with all adiposity indices, but in stepwise multiple regression analysis only waist circumference was an independent predictor of serum osteocalcin.

Contradicting the previous observation [22], Rochefort et al. [23] did not find any differences in serum osteocalcin levels in obese children compared to nonobese controls. A possible explanation for the inconsistent data linking childhood adiposity and circulating osteocalcin can be attributed to the studied group, since the relationships between markers of calcium metabolism and body composition showed racial and ethnic differences [25].

In concordance with our results, Reinher and Roth [22] reported a negative association between serum OC concentration and HOMA-IR, a measure of insulin resistance. Other paediatric studies have also shown a significant association between circulating osteocalcin concentrations and blood markers of the dysmetabolic phenotype in obese children [23, 25], although Boucher-Berry et al. [25] found such an association only 
in whites. It is possible that other variables related to adiposity, such as pubertal status, which may affect OC, were not assessed in the latter study.

Furthermore, our study revealed a gender-related difference in serum osteocalcin level in obese children and adolescents. Studied boys had significantly higher serum OC concentrations compared to girls. Such a gender-related difference constitutes an interesting finding; this phenomenon was previously documented in studies of healthy children and adolescents [27, 28]. Adjustment for BMI-SDS and fat mass (data not shown) suggests that the gender-related difference in serum OC concentration observed in our group was independent of body size. It may rather result from gender-related differences in serum 25-OH-D levels that were also observed in our study (data not shown) or from differences in growth rates during puberty. Fares et al. [28] showed that serum OC in girls is maximal at midpuberty (i.e. when the pubertal growth spurt occurs) and decreases towards the adult level by Tanner stage V. In contrast, circulating OC in boys increases during early pubertal stages but does not decrease by Tanner stage $\mathrm{V}$, and persists longer than in girls. As most of our subjects were pubertal, the effects of gender can be also explained in terms of differences in sex steroids secretion during pubertal development. Previous studies have revealed testosterone levels in boys [29] and oestrogen concentration in girls [30] to be the best predictors of bone markers.

There are several potential limitations of this study. Firstly, we measured only total osteocalcin concentration. Both forms of osteocalcin, carboxylated and under-carboxylated, are secreted by osteoblasts and released into circulation. Uncarboxylated osteocalcin is biologically active in mice, but the clinical significance of these two forms in humans is not fully explained. For instance, in one study in older men and women, serum uncarboxylated osteocalcin was not associated with insulin resistance [31] whereas Schafer et al. [32] confirmed the association between undercarboxylated OC and metabolic parameters.

Another limitation of our study was that we used only waist circumference as a surrogate of abdominal obesity. Although magnetic resonance or computed tomography would have provided more precise information about visceral fat tissue, we recognise the limitations of using these methods in children. Another important limitation to note is the lack of correlation of serum osteocalcin with bone mineral density. Further prospective studies are needed to assess the impact of low osteocalcin level on growing bones.

We were unable to demonstrate the effect of physical exercise on serum OC levels. Our group included obese children and adolescents whose level of physical activity was generally low. Further studies are under way to determine the influence of physical training, as a part of obesity intervention programme, on serum osteocalcin levels in children.

Reciprocal relationships between osteocalcin and systemic energy metabolism have been recently explained by the hypothesis about common origin of the osteoblast with the other cells involved in glucose and fat metabolism (adipocytes and muscle cells) [28]. Moreover, adipose tissue, in vitro, is able to secrete osteocalcin in both uncarboxylated and carboxylated forms [29], therefore the contribution of bone and fat tissue to circulating osteocalcin should be further investigated.

Our study in obese children and adolescents provides further insight into the regulatory hormonal loop comprising adipose tissue, insulin, and osteocalcin by taking into account metabolic risk parameters.

In conclusion, we demonstrate that serum osteocalcin levels are independently associated with parameters of the dysmetabolic phenotype, including insulin resistance, triglycerides and abdominal obesity. The potential of osteocalcin as a medication for ameliorating the dysmetabolic profile in at-risk individuals is speculative at present, but merits additional investigation.

\section{References}

1. Weiss R, Dziura J, Burgert TS et al. Obesity and the metabolic syndrome in children and adolescents. N Eng J Med 2004; 350: 2362-2374.

2. Goulding A, Jones IE, Taylor RW et al. Bone mineral density and body composition in boys with distal forearm fractures: a dual-energy x-ray absorptiometry study. J Pediatr 2001; 139: 509-515.

3. Shanahan CM, Cary NR, Metcalfe JC et al. High expression of genes for calcification-regulating protein in human atherosclerotic plaques. J Clin Invest 1994; 93: 2393-2402.

4. Lee NK, Sowa H, Hinoi E et al. Endocrine regulation of energy metabolism by the skeleton. Cell 2007; 130: 456-469.

5. Ferron M, Hinoi E, Karsenty $\mathrm{G}$ et al. Osteocalcin differentially regulates cell and adopocyte gene expression and affects the development of metabolic diseases in wild-type mice. Proc Natl Acad Sci USA 2008; 105: 5266-5270.

6. Ferron M, McKee MD, Levine RL et al. Intermittent injections of osteocalcin improve glucose metabolism and prevent type 2 diabetes in mice. Bone 2012; 50: 568-575

7. Palczewska I, Niedźwiecka Z. Somatic development indices in children and youth of Warsaw. Dev Period Med 2001; 2 (Suppl.): 113-114.

8. Nawarycz T, Ostrowska-Nawarycz L. Percentile distributions of waist circumference in children and adolescents. Pediatr Pol 2007, 82: 418-424.

9. Mathews DR, Hosker JP, Rudenski AS et al. Homeostasis model assessment: insulin resistance and beta-cell function from fasting plasma glucose and insulin concentrations in man. Diabetologia 1985; 28: 412-419.

10. Rached MT, Kode A, Silva BC et al. FoxO1 expression in osteoblasts regulates glucose homeostasis through regulation of osteocalcin in mice. J Clin Invest 2010; 120: 357-368.

11. Kim SH, Lee JW, Im JA et al. Serum osteocalcin is related to abdominal obesity in Korean obese and overweight men. Clin Chim Acta 2010; 411: 2054-2057.

12. Fernandez-Real JM, Izquierdo M, Ortega F et al. The relationship of serum osteocalcin concentration to insulin secretion, sensitivity, and disposal with hypocaloric diet and resistance training. J Clin Endocrinol Metab 2009; 94: 237-245.

13. Kindblom JM, Ohlsson C, Ljunggren O et al. Plasma osteocalcin is inversely related to fat mass and plasma glucose in elderly Swedish men. J Bone Miner Res 2009; 24: 785-791.

14. Iglesias $\mathrm{P}$, Arrieta F, Pinera $\mathrm{M}$ et al. Serum concentrations of osteocalcin protocollagen type $1 \mathrm{~N}$-terminal propeptide and beta-CrossLaps in obese subjects with varying degrees of glucose tolerance. Clin Endocrinol 2011; 75: 184-188. 
15. Zhou M, Ma X, Li H et al. Serum osteocalcin concentrations in relation to glucose and lipid metabolism in Chinese individuals. Eur J Endocrinol 2009; 161: 723-729.

16. Kanazawa I, Yamaguchi T, Yamamoto $M$ et al. Serum osteocalcin level is associated with glucose metabolism and atherosclerosis parameters in type 2 diabetes mellitus. J Clin Endorinol Metab 2009; 94: 45-49.

17. Levinger I, Zebaze R, Jerums $\mathrm{G}$ et al. The effect of acute exercise on undercarboxylated osteocalcin in obese men. Osteoporos Int 2011; 22: 1621-1626.

18. Pittas AG, Harris SS, Eliades $M$ et al. Assoiation between serum osteocalcin and markers of metabolic syndrome. J Clin Endocrinol Metab 2009; 94; 827-832.

19. Saleem U, Mosley TH, Kullo IJ. Serum osteocalcin is associated with measures of insulin resistance, adipokine levels, and the presence of metabolic syndrome. Arterioscler Thromb Vasc Biol 2010; 30: 1474-1478.

20. Yeap BB, Chubb SA, Flicker L et al. Association of total osteocalcin with all-cause and cardiovascular mortality in older men: the Health in men study. Osteoporos Int 2012; 23: 599-606.

21. Prats-Puig A, Mas-Parareda M, Riera-Perez E et al. Carboxylation of osteocalcin affects its association with metabolic parameters in healthy children. Diabetes Care 2010; 33: 661-663.

22. Reinher T, Roth CL. A new link between skeleton, obesity and insulin resistance: relationship between osteocalcin, leptin and insulin resistance in obese children before and after weight loss. Int J Obes 2010; 34: 852-858.

23. Rochefort GY, Rocher E, Aveline PC et al. Osteocalcin-insulin relationship in obese children: a role for the skeleton in energy metabolism. Clin Endocrinol 2011; 75: 265-270.

24. Pollock NK, Bernard PJ, Wenger Ket al. Lower bone mass in prepubertal children with prediabetes. J Bone Miner Res 2010; 25: 2760-2769.
25. Boucher-Berry C, Speiser PW, Carey DE et al. Vitamin D, osteocalcin, and risk for adiposity as comorbidities in middle school children. J Bone Miner Res 2012; 27: 283-293.

26. Jebb SA, Cole TJ, Doman D et al. Evaluation of the novel Tanita body-fat analyser to measure body composition by comparison with a fourcompartment model. Br J Nutr 2000; 83: 115-122.

27. Magnusson P, Hager A, Larsson L. Serum osteocalcin and bone and liver alkaline phosphatase isoforms in healthy children and adolescents. Pediatr Res 1995; 38: 955-961.

28. Fares JE, Choucair M, Nabulsi M et al. Effect of gender, puberty, and vitamin $\mathrm{D}$ status on biochemical markers of bone remodelling. Bone 2003; 33: 242-247.

29. Orwoll ES, Beknap JK, Klein RF. Gender specificity in the genetic determinants of peak bone mass. J Bone Min Res 2001; 16: 1962-1971.

30. Cadogan J, Blumsohn A, Barker M et al. Longitudinal study of bone gain in pubertal girls: anthropometric and biochemical correlates. J Bone Min Res 1998; 13: 1602-1612.

31. Shea MK, Gundberg CM, Meigs JB et al. -Carboxylation of osteocalcin and insulin resistance in older men and women. Am J Clin Nutr 2009; 90: $1230-1235$.

32. Schafer AL, Sellmeyer DE, Schwartz AV et al. Change in undercarboxylated osteocalcin is associated with changes in body weight, fat mass, and adiponectin: parathyroid hormone (1-84) or alendronate therapy in postmenopausal women with osteoporosis (the PaTH Study). J Clin Endocrinol Metab 2011; 96: E1982-E1989.

33. Fernandez-Real JM, Ricart W. Osteocalcin: a new link between bone and energy metabolism. Some evolutionary clues. Curr Opin Clin Nutr Metab Care 2011; 14: 360-366.

34. Foresta C, Strapazon G, De Toni L et al. Evidence for osteocalcin production by adipose tissue and its role in human metabolism. J Clin Endocrinol Metab 2010; 95: 3502-3506. 